\title{
Swedish Lower Secondary School Teachers' Perceptions and Experiences Regarding Homework
}

\author{
Limin Gu*, Margaretha Kristoffersson \\ Department of Education, Umeå University, Sweden
}

Copyright $@ 2015$ Horizon Research Publishing All rights reserved.

\begin{abstract}
This study investigates homework in Swedish lower secondary schools: teachers' perceptions and experiences about it and their understanding of its potentials and challenges for students' learning and development. Data collected through an online survey $(\mathrm{N}=201)$ mixed standardized questions and open questions. Descriptive statistics and qualitative interpretive principles fueled data processing and analysis. The main result indicated that most teachers assign homework and believe it will benefit students' learning when it addresses consolidating and reinforcing knowledge already taught and increases skills through repetition. They regard appropriation and variation of homework and feedback as important to homework activities and effects. The teachers experience uneven attitudes to and outcomes of homework among students. Most schools organize homework assistance activities to smooth out this unevenness and to improve homework completion and quality. The findings highlight the educational implications of critical reflections on the design of homework and the quality of homework assignments.
\end{abstract}

Keywords Homework, Swedish Lower Secondary School, Teachers' Perspective, Survey

\section{Introduction}

Homework has long been a feature in most schools around the world. The dominated discourse is that homework improves students' learning and development, communication between parents and students, and home-school cooperation [1-3]. But it has been taken for granted that homework practice fulfills these functions automatically. Previous research into this field has mainly emphasized the effects of homework regarding correlations between it and student academic achievement, but the conclusion is still far from clear $[1,4,5]$. Some research indicates positive relations between time-on-homework, homework efforts, and achievement, especially in higher grades [6-8]. Hattie [9] has analyzed a large number of studies of the factors that affect student learning. He concludes that homework has a positive but very weak effect, \#88 out of 138 influence factors. Research has also found positive relations between homework and students' study habits as well as the development of self-regulation [10,11]. However, other studies point out that too much and too difficult homework can harm students' learning by sparking poorer attitudes, irritation, and repugnance $[4,12,13]$. Indeed, homework and its effect depend on multiple factors and involve various actors: not only teachers and students but also parents and other adults. Homework phenomena are highly complex and call for examination and measurement of multiple variables and from different actors' perspectives.

In Sweden, homework has been an overlooked subject in research, and is not regulated in the national curriculum $[14,15] 1$, even though it is common in the work of the school. However, after the PISA (Program for International Student Assessment) shock $[16,17] 2$, the Swedish government has been carrying out a set of reforms such as early scores and more national tests aimed at improving students' academic performance and outcomes. One consequence in school practice is increased emphasis on application of homework. The last few years have seen dramatic increase in the number of private companies that support students' homework. The government allows tax deductions for families that have bought this kind of service3. The private homework business has grown explosively and now millions of Swedish krona are traded [18]. It seems that the Swedish students have difficulties with homework, and need resources outside the school system to help them. Debates on the effectiveness of Swedish school education and the impact of "privatization of homework" on school education and the issue of social equality are highlighted $[19,20]$. However, we seldom hear teachers' voices in these debates, and there is an absence of reflection and research examining and evaluating existing homework practice in Swedish schools. This study intends to describe and analyze homework practice in Swedish lower

1 Since 1994, there have been no specific rules on homework in school policy documents [62].

2 The Swedish students' performance deteriorated sharply in mathematics, science and reading in PISA in 2009 and in 2012, which led to critiques of Swedish school politics and the resulting reduced quality of school education.

3 RUT avdrag: the system of tax reduction for household services. 
secondary school from teachers' perspective, and discuss the potentials and challenges related to homework for students' learning and development. The research questions are:

- What are teachers' experiences with homework activities and outcomes?

- How do teachers perceive homework's purpose and the critical factors affecting its implementation and performance?

- What can be the educational implications for teachers' work?

\section{Research in the Field}

Cooper [21] defines homework as a teacher-initiated task aimed at increasing students' effective learning on their own outside of school. According to Epstein \& Van Voorhis [22], Van Voorhis [23] and Warton [24], there are mainly two purposes for homework: instructional and non-instructional. Regarding the instructional aspect, research from the last two decades has mainly demonstrated the positive influence of homework on achievement [1]. Cooper and Van Valentine [25] find a significant relationship between homework and achievement depending on students' grade levels: the positive correlations are more strongly associated with high school students than those in elementary school. This is because homework serves different purposes and thus has different types of assignments adapted to students at different grade levels. Elementary school teachers tend to use homework to improve younger students' basic skills and enforce good study habits rather than reinforce academic content $[22,24]$. In accordance with other instructional techniques, homework can produce a substantial positive effect on higher-grade students' performance at school [21]. However, research also indicates the homework-achievement association is highly complex, affected by multiple variables such as homework time and frequency, subject matter, subjective efforts, prior knowledge, cognitive abilities, school quality, emotions, motivation and volition, and gender. This calls for multilevel analysis models across different levels, such as class level, between-student level and within-student level, as well as across cultures [1,7,26-28].

Several researchers who emphasize certain behaviors, skills, and self-beliefs in relation to homework activities employ the concept of self-regulation of learning (SRL) $[5,11,29,30]$. They have argued for a positive relationship between SRL and motivation and effort in completing homework, which increases with grade [31,32]. In a literature review, Ramdass and Zimmerman [8] conclude positive relationships between homework activities and self-efficacy, self-reflection, responsibility for learning, goal setting; management of time, and maintaining attention and focus. In doing homework, students practice self-regulatory behaviors such as planning, managing, and organizing tasks; overcoming unwanted emotions; and reflecting on what has been learned. In designing and managing homework, important factors are appropriate amount and degree of difficulty of homework and teachers' explicit instructions about the tasks [33]. When homework is overly challenging it can lead to frustration, impatience, low-esteem, and lower academic self-efficiency, especially among struggling students [8].

Recent research has emphasized homework's social dimensions. For instance, a Danish research group has studied what homework means to different actors such as students and their parents in their everyday lives. They found homework has a role in conducting children's identity as "school-pupil" and making connections and boundaries between home and school, as well as functioning as an element in socialization to schooling and labor [3]. Also, some studies support a significantly positive correlation between parents' involvement in the homework process and students' homework experiences and outcomes [2,34-38]. Dumont, Trautwein, Lüdtke, Neumann, Niggli and Schnyder [39] found that positive forms of parental help with homework have a positive correlation with students' positive homework attitudes and behaviors.

More recent research, however, has addressed and discussed negative consequences of homework, especially from students' perspectives. Students have more negative attitudes towards homework with lower motivation in general because they do not see the meaning of doing homework [40,41]. Homework-related stress has also come to some attention [42-44]. Research also shows how parents' involvement connected with homework could lead to conflicts between children and parents. Disagreements on when and how to complete homework usually lead to family stress $[37,43,45]$. Some studies indicate that there is a potential danger for homework to contribute to more unequal schooling with increased gaps among students based on their backgrounds in terms of class, gender, ethnicity, family background and the school culture differences [7,46-49].

\section{Study Design}

\subsection{Data Collection}

This study was based on an online survey of lower secondary school teachers $(\mathrm{N}=201)$ from nine municipalities in Sweden. The survey, which took the form of a questionnaire, began with questions regarding background information (A) and contained four main themes consisting of a total of 69 items. The four themes are: homework activities and outcomes (B); perceptions of homework aims (C); pedagogical strategies concerning homework design and management (D); and school-organized homework assistant activities (E). The design of the themes and items was partly inspired by prior research exploring the instructional and non-instructional purposes of homework, homework types and characteristics, homework completion $[1,8,24,50]$, and partly based on knowledge and reflections on the results of the pilot teacher survey, conducted in one municipality in 2011 [51]. 
The survey was a combination of single- and multiple-choice, rating scales, and open questions [52]. Rating scale questions provide statements regarding the respondents' degrees of agreement from scales 1 to 6 , where 6 is most important (or agree mostly). Open questions are provided at the end of every theme and give the respondents the opportunity to explain the choices they made or provide other relevant thoughts and comments. Table 1 presents an overview of the distribution of the items in relation to the themes and types of questions.

Table 1. Design of the survey

\begin{tabular}{|c|c|c|c|c|c|}
\hline $\begin{array}{l}\text { Types Themes } \\
\text { of question }\end{array}$ & A & B & C & D & E \\
\hline Single/multiple-choice & 7 & 8 & 0 & 0 & 11 \\
\hline Rating scale & 0 & 0 & 22 & 9 & 5 \\
\hline Open question & 1 & 1 & 1 & 1 & 3 \\
\hline Total & 8 & 9 & 23 & 10 & 19 \\
\hline
\end{tabular}

\subsection{Procedure, Participants and Ethical Consideration}

The selection of municipalities was based on distribution in terms of geographical locations that represent different parts of the country such as northern, middle, southern, coastal and inland areas, as well as different population sizes in order to provide a wider range of samples with different circumstances [53]. Telephone contact was made in March 2012 with persons responsible for education of grades 7-9 in the educational departments in 15 municipalities. Of these 15 municipalities, only nine gave positive responses. Among these nine municipalities, one is located in the southern part of Sweden, four in the northern part, and four in the middle part. Five municipalities are located in inland areas, while the other four are in coastal areas. The population sizes also differ; there are three small municipalities with 10,000-15,000 inhabitants, one large city with almost 200,000 inhabitants, and five middle-sized municipalities with between 55,000 and 97,000 inhabitants. Politically and ideologically there are not as many differences among those municipalities because of the country's governing system. However, in terms of school education there could be some differences in terms of economic resources because of the municipalization of education in the early 1990s 4 that followed the decentralization of education [54]. The current study was not intended to compare the differences among schools from the different municipalities, but tried to involve varied samples to represent as many different circumstances as possible in order to provide a general picture of the research objectives [53].

After telephone contact, information about the study was sent to the contact persons in each municipality via e-mail. All grade 7-9 teachers in public schools were invited to participate in the survey. Together with a missive letter

4 Municipalization of school was implemented in 1991 with the aim of transferring more responsibility for the Swedish school system from the state to local governments. where the research aim and principle of confidentiality is explained, the online address linking to the survey was sent to the contact person in each municipality and then sent further to all lower secondary school teachers via their e-mail systems within respective municipalities. A reminder notice was sent to all participants on the mail lists through the contact persons in the municipalities after the first deadline was passed. Finally, 212 teachers filled out the online survey, of which 11 were not completed or made errors, which means a total 201 questionnaires were available.

\subsection{Attrition of Survey Response}

The total population of teachers in this category was about 550 in 2012, according to the information gathered from the nine municipalities 5 . As we can see, the response rates were low in this case $(36.5 \%)$. There are two likely reasons for the larger attrition of response. First, teachers work under great pressure in terms of lack of time, which has been a well-known factor. In the current study, it seemed that a quite large number of teachers did not give priority to answering the questionnaire. The Web-based survey, in which participation was voluntarily and anonymous and incentives were not applied, put higher demands on the participants' willingness and their priority, which could have caused the lower response rates [55]. Ejlertsson [56] also points out that the proportion of participants in various surveys has decreased radically during recent decades, partly because of the development of the information and communication society, in which most people are exposed to a barrage of advertising and information that affects their motivation to participate in surveys. The second reason could be, as we mentioned earlier, Swedish teachers have been quite silent in the public debate and discussions on homework, which could mean a lower level of teacher interest in this topic in general. If this was the case, the low response rates also could signal the lack of teachers' emphasis and reflection on homework issues in Swedish lower secondary schools.

\subsection{Data Processing and Analysis}

This study aims to learn about teachers' experiences, understanding, opinions, and attitudes towards homework. There is no intent to prove cause-and-effect and correlations among the variables. A descriptive statistics approach is adopted to measure and analyze the main data from survey [52]. A number of analytical strategies and functions in Excel are used to measure and interpret different types of data including single- and multiple-choice questions, nominal scales, and ordinal scales.

Because the distances between adjacent scales in the rating-scale questions are not equal to each other, the scales should be regarded as ordinal. It was therefore more

5 Several municipalities could only provide an approximate number of available teachers in this category during the period of investigation because of the mobility of the teachers in terms of sickness, parental leave, retirement, etc. 
appropriate to measure median (i.e., MD, fiftieth percentile), mode (the most frequently occurring number) and interquartile ranges (i.e., IQR, distributional measurements on variation or spread) instead of measuring mean and standard deviations, in order to provide an accurate picture of the central tendencies and their variations in teachers' answers [52]. Data from open questions in the survey in form of free text are analyzed by adapting the systematic process of developing codes and themes in relation to the research objectives that involves an integrated process of reading, interpreting and reflection [57]. The teachers' comments provide us with richer and contextualized information that supports identifying, illustrating, and understanding the tendencies emerging in the questionnaire [58].

\section{Main Findings}

A total of 201 teachers $(\mathrm{N}=201)$ completed the Web-based survey; the dominant group was female teachers $(\mathrm{N}=160,80 \%)$.

Table 2. Background information of the teachers

\begin{tabular}{|c|c|c|c|c|}
\hline Personal info. & Mean & SD & Min & Max \\
\hline Age (year) & 46 & 9.32 & 25 & 65 \\
\hline teacher qualification (year) & 16 & 9.94 & 0 & 40 \\
\hline working as teacher (year) & 15 & 9.77 & 0.4 & 40 \\
\hline
\end{tabular}

Table 2 presents some background information about the teachers, indicating a rather heterogeneous respondent group $(\mathrm{SD}>9)$, which means that teachers' experiences could differ greatly. The teachers represent all school subjects, but the greatest groups are language (Swedish $31 \%$, English $26 \%$, and other languages $14 \%$ ), mathematics ( $31 \%$ ), science studies $(24 \%)$, and social studies teachers $(21 \%) 6$.

\subsection{Homework Activities and Outcomes}

A total of 166 teachers $(83 \%)$ report that they do assign homework in their respective teaching subjects. Thirty-five teachers $(17 \%)$ do not assign homework, and therefore skipped questions concerning the types, subjects, time, frequency and outcomes of homework assignments. The following percentages presented in this section are based on $\mathrm{N}=166$. The major types of homework assignments are reading $(\mathrm{N}=94,57 \%)$, writing $(\mathrm{N}=90,54 \%)$, memorizing vocabulary $(\mathrm{N}=73,44 \%)$, counting $(\mathrm{N}=50,30 \%)$, project work $(\mathrm{N}=50,30 \%)$ and mathematical problem solving $(\mathrm{N}=$ $36,22 \%$ ), where multiple choices are allowed. Swedish, mathematics, English, other languages, nature studies, and social studies are the subjects in which the most homework was assigned. Ninety seven teachers (58 \%) give homework less than once a week, and 61 teachers $(37 \%)$ assign homework once or twice a week. Only one teacher assigns homework every day. More than half the teachers estimate

6 In the Swedish school system, a teacher has to be qualified at least in two main subjects. that students need 15-30 minutes to complete their homework each week. Only 12 teachers estimate that the students need more than one hour to finish the homework within a week. It seems that the amount of homework and the time required to complete it are not demanding in general. However, how much time student spend doing homework differs depending on the characteristics of the assignments and students' individual circumstances, as observed by some teachers. The estimated time that teachers reported only refers to their own teaching subjects, which means that a student could have several homework assignments from different subject teachers during a week.

Generally, the teachers are quite positive regarding students' outcomes of homework. More than half of the teachers feel that the students complete homework well. Only $12 \%$ of teachers report negative results from homework. However, a total of 84 teachers have made comments in the open question, and their comments reveal more negative experiences. The majority recognizes distinctions among student groups: some of them always do their homework and many complete the homework with good results, but some of the students never do homework or do not submit it on time. It is therefore hard to give a general answer to this question, according to the teachers surveyed.

In teachers' comments, words such as students' attitudes, motivation, special needs, leisure time activities are frequently mentioned, and could therefore be understood as critical variables identified by the teachers that affect the completion and outcomes of homework by students. The following are some examples:

The attitude many students have is that school work should be done during school time and not in their leisure time, and homework is only needed before the tests. There are of course many who always do their homework, but I see a clear tendency that more and more students do not (do their homework). (Teacher no. 122)

They (students) don't understand what is best for them and the value of repetition. There is no immediate and direct link between "to do homework" and to learn things or to get scores. They often choose the easy way and prefer a fun leisure time activity more than homework that sometimes is "tough." (Teacher no. 30)

I have many students with social difficulties (teenagers!), and to do homework could sometimes be more difficult than to hang out with friends! (Teacher no. 35)

According to a number of teachers, homework can benefit study-motivated and goal-oriented students who always carry out homework and have better outcomes. The gap regarding study results between those students and "struggling" students thus becomes bigger because of homework: Some students work well with homework and it gives results. Those who do not do their homework are those who are not doing well (in school) (Teacher no. 154). As teacher no 159 also says: Those who are 'talented' do their homework and have good results, and those who have difficulty in meeting the goals ignore (homework) more often. 


\subsection{Perceptions of the Purpose of Homework}

A total of 23 items were related to this theme, of which 22 were rating scale questions and one was an open question. Full results from the rating scale items concerning teachers' perception regarding the purposes of homework are presented in Appendix 1.

The results show that teachers give the highest value to reinforcing and consolidating knowledge already gained and to practicing skills through repetition (see Appendix 1, items 1 and 2), where scale 6 (agree mostly) is preferred as both the fiftieth percentile score (median) and the most frequently occurring score (mode). Furthermore, the interquartile ranges are at level one for both items, indicating a very small deviation from the median values, which shows that teachers have common perceptions regarding these statements. Homework is seen as most useful for subjects such as mathematics and language because language and mathematics require some extended knowledge, which students have difficulty to learn only during class period, that must be repeated over time to be consolidated (teacher no. 47). Teacher no. 117 also points out that it is important to have homework, especially in mathematics. Then, the students repeat the basics and work out what they are doing right in the current field. According to a number of teachers, homework is important in language learning in terms of memorizing new words so students can build up their vocabularies. In the teachers' comments, repetition is a term often mentioned. I believe that homework should exist, but that they should have the function of repetition or shorter reading assignments, as teacher no. 29 says.

The findings also indicate that teachers generally do not pay attention to the non-instructional purposes of homework; only item 16 regarding students' ability to take responsibility for themselves has the typical value on highest level (mode $=$ 6, see Appendix 1). We can also read in the table that the largest group of teachers do not see relations between homework and the development of students' self-regulation, better time-management abilities, and parental involvement (see Appendix 1, items from 17 to 20, where mode =1). As for the notion that homework is for the sake of tradition or parents' requirement, a majority of the teachers totally disagree with such statements, with very small or no deviations from the median values, indicating a common view among teachers (see Appendix 1, items 21 and 22).

\subsection{Pedagogical Premise}

Table 3 reveals the levels of teachers' preferences in dealing with factors that are relevant to homework design and management. The teachers believe that the appropriate degree of difficulty and amount of homework are the most important factors that should be taken into account when assign homework (see items 1 and 2, where the both median and mode are at level 6 , and the IQR is at level one, indicating a very small deviation from the median). Other factors such as the form and type of homework are also of importance. According to teacher no. 30, homework should be backward-looking and repetitive in its nature. It could be only reading a short text for understanding. Homework in completely new areas will not be given to younger ages (up to age 7). Feedback (item 3 ) is also regarded as an important factor. All 166 teachers who assign homework report that they all give feedback on homework using different methods (multiple choices are permitted). Among these methods, the frequently used feedback strategies include the teacher correcting and giving written comments on individual students' homework (62\%), or the student demonstrates his/her homework to the whole class (42\%).

The largest group of teachers also indicates the importance of factors such as giving consideration to students' motivations and their individual conditions, as well as the variation of homework (items 4, 5 and 6). As we can also see, information communication technologies (ICT) are not regarded as important means and tools for homework practices (item 9).

Table 3. Pedagogical premise regarding homework design and assignment

\begin{tabular}{|c|c|c|c|c|}
\hline Item & Pedagogical ideas behind homework design & MD* & Mode & IQR \\
\hline 1 & Students should be able to understand the task and able to solve it by themselves & 6 & 6 & 1 \\
\hline 2 & Homework should be given in moderate amounts & 6 & 6 & 1 \\
\hline 3 & Students should be given feedback on their homework & 5 & 6 & 2 \\
\hline 4 & Homework should take into account students' individual circumstances and needs & 5 & 6 & 2 \\
\hline 5 & Homework should motivate and stimulate students' learning & 5 & 6 & 2 \\
\hline 6 & Homework should be varied & 4 & 6 & 3 \\
\hline 7 & Homework should be interesting for the students & 4 & 4 & 2 \\
\hline 8 & Homework should be given in cooperation and coordination among subject teachers & 4 & 4 & 3 \\
\hline 9 & Modern technologies and Internet resources should be taken into account to be \\
utilized & 3 & 1 & 2 \\
\hline
\end{tabular}

$* \mathrm{MD}=$ median; $* * \mathrm{IQR}=$ interquartile ranges 
In teachers' comments, the importance of giving clear instructions for homework assignments has been addressed. Some teachers also wish to be free from homework or minimize homework. They believe that if students would work more effectively during their school time, it would not be necessary to assign homework. As one teacher says:

My opinion is actually - so little homework as possible, and most of the homework should be done during school hours. Those who do not receive the support they need at home can be even more behind with the school work. (Teacher no. 1)

\subsection{Homework in School}

Actually, many schools have been trying to carry out homework in school. It is reported by most of the teachers (N $=150,75 \%)$ that there are organized homework activities during school hours in their schools, instead of homework at home. According to teachers' descriptions, the activities are organized directly after the school time in most cases and students are not obligated to attend, even though this activity is sometimes on the school schedule.

The form, content, and structure of activities differ among schools; more than half of the teachers $(\mathrm{N}=96)$ report that this kind of activity is organized once a week, and 35 teachers $(\mathrm{N}=35)$ report that such activities occur two or more times a week. In most cases $(\mathrm{N}=148)$, one or more teachers/educators are available to support the students during the activities. The students also have the opportunity to help each other $(\mathrm{N}=131)$. More than half of the teachers $(\mathrm{N}=115)$ report that the homework assistance activities in their schools mix students from different grades.

However, the activity is more critical in practice. Many teachers point out deficiencies in the arrangement of homework assistance activities. In most schools, the students show a weak interest in participating in such activities. In many cases, the students who need support with homework do not utilize the opportunity (Teacher no. 39). The students do not take the opportunity to use the homework assistance activities and do not use the time effectively (Teacher no. 12). It seems that the communication among the class teachers, subject teachers, and the teachers who are in charge of the homework activities is poor. As one teacher writes: There are not always teachers there who hold the homework activities. It is not unusual that the activities were deleted because the teachers in charge were absent - which we seldom be informed in advance (Teacher no. 3). Lack of resources in terms of time for teachers to plan, manage, and evaluate the activities is mentioned in many teachers' comments. Some teachers point out defects at the level of school leadership and management in terms of inadequate planning with regard to scheduling and tasks.

Homework assistance in our school is during our working team time when we have meeting/planning. The teacher that has students attending the homework assistance must be "in two places at the same time", and then go between the meeting and students. (Teacher no. 75)
Table 4 shows the tendencies regarding who the teachers think the organized homework assistance activities will benefit. It seems that the teachers have a common view that such activities will benefit students who need more support for various reasons (items 1 and 2). The statement that homework could provide opportunities to challenge talented students is not highly valued, with a median value of 3 (MD $=3$ ) and mode value of 1 . However, there is a quite wider distribution among the teachers' answers (IQR $=3$ ), suggesting that teachers do not have common understanding of the statement.

Table 4. Teachers' opinion on organized homework assistance activities in school

\begin{tabular}{|c|c|c|c|c|}
\hline Item & Homework in school will benefit: & MD* & Mode & $\mathrm{IQR}^{* *}$ \\
\hline 1 & $\begin{array}{c}\text { Students who cannot get support at } \\
\text { home }\end{array}$ & 6 & 6 & 2 \\
\hline 2 & Students who have special needs & 5 & 6 & 1 \\
\hline 3 & $\begin{array}{c}\text { Increasing homework } \\
\text { completion }\end{array}$ & 4 & 6 & 2 \\
\hline 5 & $\begin{array}{c}\text { Students who have a lot of activities } \\
\text { during } \\
\text { leisure time }\end{array}$ & 4 & 6 & 2 \\
\hline & $\begin{array}{c}\text { Talented students who need to be } \\
\text { challenged }\end{array}$ & 3 & 1 & 3 \\
\hline
\end{tabular}

*MD $=$ median $; * * \mathrm{IQR}=$ interquartile ranges

\section{Discussion}

This study investigates and analyzes the teachers' experiences of homework activities and their understandings of the purposes and functions of homework, as well as the potential and challenges related to homework implementation. The ambition is to gain insight into homework practices in Swedish lower secondary schools and contribute to knowledge regarding its educational implications.

The results indicate that homework is a common practice in Swedish schools, although it is not regulated in the national curriculum $[12,13]$. The absence of regulation in the use of homework means that it is up to teachers, on the basis of their respective mandates, to determine whether and how they want to include homework as part of the educational activities in their classrooms. In the current study, the majority of teachers do assign homework in most school subjects, applying different types and strategies. This practice can be understood in relation to teachers' perceptions of the purpose of homework. The results reveal that both instructional and non-instructional purposes of homework are realized by the teachers, but they tend to prefer instructional purposes, as presented in Appendix 1. Despite the unclear correlation between homework and achievement, as many researchers indicate $[1,2,4,24]$, it seems that among teachers there is a quite strong belief that homework can fulfill the function of improving students' learning and academic achievement. They argue that homework benefits students' learning when it addresses 
reinforcing knowledge that has already been taught in classroom and increases skill proficiency through repetition and exercises. This result confirms the findings of previous international research showing that teachers tend to use homework to reinforce academic content for students at higher grade levels, such as secondary schools [19-22]. However, in contrast to findings from previous studies $[8,9,28]$, teachers in this study do not realize correlations between homework and the development of students' self-regulation and time-management abilities (see item 17 and 18 in Appendix 1), which could be a consequence of teachers' emphasis on the instructional purpose of homework. It could also be a result of teachers' more negative experiences and concerns regarding the outcomes of homework.

The results also indicate that most teachers are aware of the importance of pedagogical and didactical aspects in relation to the design and management of homework. They highlight the necessity of determining the appropriate degree of difficulty and amount of homework assignments (see Table 3). Previous research also provided evidence that too many homework assignments could cause additional stress on students and negatively impact their homework behaviors in terms of irritation and repugnance, which could influence the homework completion in a negative way. If homework is too much and too difficult, students may be overwhelmed and thus experience homework-related weariness and lose the motivation and desire to complete homework $[1,2,6,10,11]$.

However, teachers report that even when the homework given is not demanding in terms of either the amount or the time required to complete it, they experience some deficiencies in homework outcomes. A great number of the total 84 comments describe issues such as uneven attitudes and quality levels among the students, as well as the low ratio of completion and delayed submission time. According to the teachers, this may be due to students' lower motivation and insufficient support in completing homework. Research on students' experiences and attitudes toward homework indicates that their motivation and effort concerning homework are affected by their perceptions of homework quality, control, conscientiousness, expectancy and value beliefs, at both class and individual levels [59]. In a previous study, students reported that a great part of their homework was the same assignment they had done in class, which resulted in the students not seeing the value of doing homework [40]. This could be discussed in relation to teachers' emphasis on applying repetition as the main task of homework in the current study. In a learning context, it is necessary to practice and exercise knowledge and skills through repetition. However, it could be easy to generate a misunderstanding that repetition means monotonous and simple repetitive exercises. In such a case, repetition could be perceived by the students as boring and meaningless, therefore negatively affecting their motivation and willingness to do homework. Bempechat [32] highlights the importance of making homework more meaningful for students as a conditional factor affecting the efforts and outcomes of homework. A meaningful assignment requires clear instructions, variation of tasks, and timely feedback, as well as taking into account students' individual circumstances and needs in order to increase their motivation and interest [31], as the majority of teachers in this study agree (see Table 3 ).

In line with the findings of previous research [47-49, 60], teachers in this study also recognize that the gaps among students with diverse family backgrounds and individual conditions have been critical challenges for homework activities, and homework in turn could have contributed to increasing these gaps. Therefore, they see school-organized homework assistance activities as a potential strategy for dealing with this issue. According to the teachers, this kind of activity initiated by schools could benefit "struggling" students, for instance, students with special needs and who those cannot get support at home. For those students, during the activities, teachers could have the opportunity to give explicit instructions about the tasks and thus provide subject-specific, content-related support, which is important in terms of providing the "scaffolding" for learning [61]. When interactions with the students during these activities are more content related and goal oriented, teachers could also have more opportunities to identify individual students' abilities and predict what the students can do independently in the future [61]. However, the results of this study indicate a lack of activity management at the organizational level in many schools, indicating a need for more reflection, more resources, more strategies to engage students' participation, and more collaboration among teacher teams.

\section{Conclusion and Recommendations}

The findings provide evidence of both positive and negative experiences of homework practices among teachers, reflecting their understanding of the potential and challenges associated with homework. While homework is considered necessary to improve student performance, teachers were not as optimistic about its social functions as previously assumed. Completion and outcomes of homework are the issues of concern for the teachers, who also recognize the danger of unequal schooling related to homework activities. While homework would benefit students who are focused and motivated to study, it may be unfavorable for the struggling students with lower study motivation and less support from home, which could lead to increasing the gap between students based on their backgrounds and levels of motivation. If homework is to benefit all students, it is important to adapt its coverage and difficulty to students' levels and individual conditions. Homework at home may not be the best way of reinforcing students' knowledge and skills; instead, homework activities organized and managed by teachers in schools might contribute to more equitable and effective schooling. The pedagogical implications for the teacher's work imply not assigning homework for homework's sake 
without critically examining its quality, and not taking for granted that homework automatically achieves positive functions. If homework is meant to achieve educational goals in the curriculum, teachers should be expected to reflect on what, why and how homework can be designed and managed to improve student learning and development.

\section{Limitations and Further Research}

Due to the limited number of samples, the results of this study cannot be generalized. The ambition was to involve all lower secondary school teachers in nine municipalities, but the rate of responses to the survey were low. It is difficult to know the actual reasons why many teachers did not answer the questionnaire, but lack of time has been a well-known factor in the teaching profession. The survey consists of a total 69 items, which might have contributed to the number of teachers who chose not answer the questionnaire because of time constraints. Furthermore, we should be cautious with the findings from the survey, due to the use of self-reported data. Although the respondents had the opportunity to provide additional answers or comments at the end of every theme, their answers were relatively short, which could be a limitation for contextual and holistic interpretations of the results. Interviews with teachers representing schools with different circumstances and different subject would be warranted in order to develop a more contextualized and comprehensive understanding of the complex phenomenon of homework. Furthermore, students are the main actors regarding homework activities, and their experiences and opinions are definitely important in this research field. Parents' and school leaders' perspectives are also crucial, especially regarding the support and resources necessary for better results from homework. Longitudinal case studies should be conducted in the future to examine homework assignments and practices and identify good examples for educational implications.

\section{Acknowledgements}

This work was supported by Umeå School of Education at Umeå University under Grants Dnr. 223-3122-10 and Dnr. 223-1004-13.

\section{Appendix 1}

Teachers' perceptions of the purposes of homework

\begin{tabular}{|c|c|c|c|c|}
\hline Item & Purpose of homework & Median & Mode & $\begin{array}{c}\text { Interquartile } \\
\text { ranges }\end{array}$ \\
\hline 1 & $\begin{array}{l}\text { Reinforcing and consolidating knowledge that has already been introduced in } \\
\text { class }\end{array}$ & 6 & 6 & 1 \\
\hline 2 & Practicing skills through repetition & 6 & 6 & 1 \\
\hline 3 & Preparing for tests and improving performance & 4 & 6 & 2 \\
\hline 4 & Developing good learning techniques and working habits & 4 & 5 & 2 \\
\hline 5 & Providing opportunities to deepen knowledge and take challenges & 4 & 4 & 2 \\
\hline 6 & Applying individualized learning & 3 & 4 & 3 \\
\hline 7 & $\begin{array}{l}\text { Introducing students to new material that the teacher will present in the coming } \\
\text { lesson }\end{array}$ & 3 & 4 & 2 \\
\hline 8 & Providing opportunities and time to reflect on own learning & 3 & 3 & 3 \\
\hline 9 & $\begin{array}{l}\text { Providing opportunities to utilize resources outside of school such as the library, } \\
\text { Internet, reference literature and other community resources }\end{array}$ & 3 & 1 & 3 \\
\hline 10 & Providing opportunities to carry out bigger projects extending for longer periods & 3 & 1 & 3 \\
\hline 11 & Providing opportunities to work independently & 3 & 1 & 2 \\
\hline 12 & Shifting the learning environment & 2 & 1 & 3 \\
\hline 13 & $\begin{array}{l}\begin{array}{l}\text { Facilitating the achievement of goals of the curriculum that cannot be covered in } \\
\text { school }\end{array}\end{array}$ & 2 & 1 & 3 \\
\hline 14 & Assessing students' knowledge and skills & 1 & 1 & 2 \\
\hline 15 & Providing opportunities for collaborative learning with peers & 1 & 1 & 2 \\
\hline 16 & Improving students' abilities to take personal responsibility & 4 & 6 & 3 \\
\hline 17 & Developing students' self-discipline/regulation & 3 & 1 & 4 \\
\hline 18 & $\begin{array}{l}\text { Improving students' abilities in time management and performing tasks more } \\
\text { efficiently }\end{array}$ & 3 & 1 & 3 \\
\hline 19 & Providing parents the opportunity to become involved in the child's schooling & 3 & 1 & 2 \\
\hline 20 & Providing parents the opportunity to have insight into school work & 3 & 1 & 2 \\
\hline 21 & Meeting the requirements of parents to provide homework & 1 & 1 & 1 \\
\hline 22 & It is a tradition to assign homework & 1 & 1 & 0 \\
\hline
\end{tabular}




\section{REFERENCES}

[1] Cooper, H., Robinson, J. C. \& Patall, E. A. (2006). Does homework improve academic achievement? A synthesis of research 1987-2004. Review of Educational Research. 76 (1), $1-69$.

[2] Van Voorhis, F.L. (2011b). Adding families to the homework equation: A longitudinal study of family involvement and mathematics achievement. Education and Urban Society. 43 (3), 323-338.

[3] Dannesboe, K.I., Kryger, N., Palludan, C. \& Ravn, B. (2010). The social world of children's homework. International Journal of Parents in Education. 4 (4), 11-22.

[4] Dettmers, S., Trautwein, U. \& Lüdtke, O. (2009). The relationship between homework time and achievement is not universal: Evidence from multilevel analysis in 40 countries. School Effectiveness and School Improvement. 20 (4). 375-405.

[5] Trautwein, U. \& Koller, O. (2003). The relationship between homework and achievement: Still such a mystery. Educational Psychology Review. 15 (2), 115-145.

[6] Trautwein, U. (2007). The homework-achievement relation reconsidered: Differentiating homework time, homework frequency, and homework effort. Learning and Instruction. $17,372-388$.

[7] Trautwein, U., Lüdke, O., Schnyder, I. \& Niggli, A. (2006). Predicting homework effort: Support for a domain-specific, multilevel homework model. Journal of Educational Psychology. 98 (2), 438-456.

[8] Zimmerman, B. J. \& Kitsantas, A. (2005). Homework practices and academic achievement: The mediating role of self-efficacy and perceived responsibility beliefs. Contemporary Educational Psychology. 30, 397-417.

[9] Hattie, J. (2009). Visible Learning. London: Routledge.

[10] Ramdass, D. \& Zimmerman B. (2011). Developing self-regulation skills: The important role of homework. Journal of Advanced Academics. 22 (2), 194-218.

[11] Xu, J. \& Wu, H. (2013). Self-regulation of homework behavior: Homework management at the secondary school level. The Journal of Educational Research. 106, 1-13.

[12] Hellsten, J. O. (2000). Skolan som Barnarbete och utvecklingsprojekt. En studie av hur grundskoleelevers arbetsmiljö skapas - förändras - förblir som den är (Diss.). Uppsala: Uppsala universitet.

[13] Xu, J. (2009). School location, student achievement, and homework management reported by middle school students. The School Community Journal. 19, 27-43.

[14] Lpo 94. (1994). Läroplan för det obligatoriska skolväsendet, förskoleklassen och fritidshemmet. Stockholm: Skolverket.

[15] Lgr 11. (2011). Läroplan för grundskolan, förskoleklassen och fritidshemmet. Stockholm: Skolverket.

[16] Skolverket (2009). Sverige tappar $i$ både kunskaper och likvärdighet. Online Available: http://www.skolverket.se/publikationer?id = 2473

[17] Skolverket (2012). Likvärdig utbildning i svensk grundskola? En kvantitativ analys av likvärdighet över tid. Rapport 374, Stockholm. Online Available: http://www.skolverket.se/publikationer?id=3322

[18] Röstlund, L. (2013). Läxhjälp - en miljonindustri. Online Available:http://www.aftonbladet.se/nyheter/article1534837 1.ab.

[19] Larsson, L. (2012). Regeringen kör över kritik mot läxhjälp. VK, November 7, 2012.

[20] Nilsson, M. (2012). Läxhjälp -- ett tecken på misslyckad skolpolitik. SvD, September 3, 2012.

[21] Cooper, H. (2001). The battle over homework: Common ground for administrators, teachers, and parents ( $\left.2^{\text {nd }} \mathrm{Ed}.\right)$. Thousand Oaks, CA: Corwin Press.

[22] Epstein, J.L. \& Van Voorhis, F.L. (2001). More than minutes: teachers' roles in designing homework. Educational Psychologist. 36, 181-193.

[23] Van Voorhis, F. L. (2004). Reflecting on the homework ritual: Assignments and designs. Theory into Practice. 43 (3), 205-212.

[24] Warton, P. M. (2001). The forgotten voices in homework: Views of students. Educational Psychologist. 36 (3), 155-165.

[25] Cooper, H. \& Van Valentine, J. C. (2001). Using research to answer practical questions about homework. Educational Psychologist. 36, 143-153.

[26] Cooper, H. (2007). The battle over homework: Common ground for administrators, teachers, and parents. Thousand Oaks, Calif.: Corwin Press.

[27] Falch, T. \& Rønning, M. (2011). Homework assignment and student achievement in OECD countries. Working Paper Series. No. 5/2011. Department of Economics, Norwegian University of Science and Technology. Online Available: http://www.svt.ntnu.no/iso/WP/2011/5_homework.pdf

[28] Trautwein, U. \& Lüdtke, O. (2007). Student's self-reported efforts and time on homework in six school subjects: Between-students' differences and within-students' variation. Journal of Educational Psychology. 99, 432-444.

[29] Pintrich, (2004). A Conceptual Framework for Assessing Motivation and Self-Regulated Learning in College Students. Educational Psychology Review. 16 (4), 385-407.

[30] Zimmerman, B. J. (2008). Investigating self-regulation and motivation: Historical background, methodological developments, and future prospects. American Educational Research Journal. 45 (1), 166-183.

[31] Bembenutty, H. (2009). Self-regulation of homework completion. Psychology Journal. 6, 138-153.

[32] Bempechat, J. (2004). The motivational benefits of homework: A social-cognitive perspective. Theory into Practice. 43 (3), 189-196.

[33] Cooper, H., Lindsay, J., Nye, B. \& Greathouse, S. (1998). Relationships among attitudes about homework, amount of homework assigned and completed and student achievement. Journal of Educational Psychology. 90 (1), 70-83. 
[34] Patall, E. A., Cooper, H. \& Robinson, J. C. (2008). The effects of choice on intrinsic motivation and related outcomes: A meta-analysis of research findings. Psychological Bulletin. 134, 270-300.

[35] Pomerantz, E. M., Moorman, E.A. \& Litwack, S.D. (2007). The how, whom, and why of parents' involvement in children's academic lives: More is not always better. Review of Educational Research. 77, 373-410.

[36] Pomerantz, E. M., Ng, F.F. \& Wang, Q. (2006) Mothers' mastery-oriented involvement in children's homework: Implications for the well-being of children with negative perceptions of competence. Journal of Educational Psychology. 98, 99-111.

[37] Van Voorhis, F. L. (2003) Interactive homework in middle school: Effects on family involvement and science achievement. The Journal of Educational Research. 96 (6), 323-338.

[38] Van Voorhis, F.L. (2011a). Costs and Benefits of Family Involvement in Homework. Journal of Advanced Academics. 22 (2), 220-249.

[39] Dumont, H., Trautwein, U., Lüdtke, O., Neumann, M., Niggli, A. \& Schnyder, I. (2012). Does parental homework involvement mediate the relationship between family background and educational outcomes? Contemporary Educational Psychology. 37 (1), 55-69.

[40] Gu, L. \& Kristoffersson, M. (2010). Hemma blir som skola - elevperspektiv på hemläxor. Locus. ISSN 1100-3197, No. 4, 2010. 52-67. Stockholm universitet.

[41] Hong, E., Wan, M. \& Peng, Y. (2011). Discrepancies between students' and teachers' perceptions of homework. Journal of Advanced Academies. 22 (2), 280-308.

[42] Corno, L. \& Xu, J. (2004). Homework as the job of childhood. Theory into Practice. 43 (3), 227-233.

[43] Forsberg, L. (2007). Homework as serious family business: Power and subjectivity in negotiations about school assignments in Swedish families. British Journal of Educational Psychology. 26, 209-222.

[44] Westlund, I. (2004). Läxberättelser - läxor om tid och uppgift. Linköping: Institutionen för beteendevetenskap, Linköpings universitet.

[45] Symeou, L. (2013). Mind the gap! Greek-Cypriot parents and their children's homework. In R. Deslandes (Ed.). International Perspectives on Student Outcomes and Homework - Family-School-Community Partnership. pp. 76-94. London and New York: Routledge.

[46] de Carvahlo, M. E. P. (2009) Homework, gender and family-school relations. In: Deslandes, R. (Ed.) International perspectives on student outcomes and homework. London \& NY: Routledge.

[47] Kralovec, E. \& Buell, J. (2001). The end of homework: How homework disrupts families, overburdens children, and limits learning. Boston, MA: Beacon Press.

[48] Torres, M. N. \& Hurtado-Vivas, R. (2011). Playing fair with Latino parents as parents, not teachers: Beyond family literacy as assisting homework. Journal of Latinos and Education. 10 (3), 223- 244.

[49] Wingard, L. \& Forsberg, L. (2009.). Parent involvement in children's homework in American and Swedish dual-earner families. Journal of Pragmatics, August 2009, 1576-1595.

[50] Blazer, C. (2009). Literature review homework. Online Available: http://files.eric.ed.gov/fulltext/ED536245.pdf

[51] Gu, L. \& Kristoffersson, M. (2012). Teachers' perspective on homework in Swedish elementary school. The $40^{\text {th }}$ NFPF/NERA Congress, Everyday life, education and their transformations in a Nordic and globalized context, March $8^{\text {th }}-10^{\text {th }} 2012$, Copenhagen, Denmark.

[52] Johnson, B. \& Christensen, L. (2004). Educational Research: Quantitative, Qualitative, and Mixed Approaches (2 ${ }^{\text {nd }}$ ed.). Boston: Pearson Education.

[53] Bryman, A. (2008). Social Research Methods. (3 ${ }^{\text {rd }}$ ed.). New York: Oxford University Press.

[54] Government Bill (1989/90:41). On municipal mandate for teachers, principals, assistant principals, and SYO-functionaries. Stockholm: The Swedish Parliament.

[55] Lefever, S., Dal, M. \& Matthíasdóttir, A. (2007). Online data collection in academic research: advantages and limitations. British Journal of Educational Technology. 38 (4), 574-582.

[56] Ejlertsson, G. (2014). Enkäten I praktiken - en handbook I enkätmetodik. Lund: studentlitteratur.

[57] Hjerm, M. \& Lindgren, S. (2011). Introduktion till Samhällsvetenskaplig Analys. Malmö: Gleerups Utbildning AB.

[58] Kvale, S. \& Brinkmann, S. (2009). Den Kvalitativa Intervjun. Lund: Studentlitteratur.

[59] Trautwein, U. \& Lüdtke, O. (2008). Predicting homework motivation and homework effort in six school subjects: The role of person and family characteristics, classroom factors, and school track. Learning and Instruction. 19, 243-258.

[60] Harris, A. \& Goodall, J. (2008). Do parents know they matter engaging all parents in learning. Educational Research. 50 (3), 277-289.

[61] Vygotsky, L. S. (1978). Interaction between learning and development. In M. Gauvain \& M. Cole (Eds.). Readings on the Development of Children. pp. 29-36. New York: W. H. Freeman and Company.

[62] Skolverket (2014). Läxor i praktiken - ett stödmaterial om läxor $i$ skolan. Stockholm. Online Available: http://www.skolverket.se/publikationer?id $=3340$ 